\title{
The effect of timing temporary cements to treat induced pulp necrosis in the teeth of dogs 1
}

\author{
Léslie M. Domingues-Falqueiro², Jonathan Ferreira², Fernanda M. Lopes², Agnes \\ Tymoszczenko ${ }^{3}$ and Marco A. Gioso ${ }^{4}$
}

\begin{abstract}
Domingues-F.L.M., Ferreira J., Lopes F.M., Tymoszczenko A. \& Gioso M.A. 2007. The effect of timing temporary cements to treat induced pulp necrosis in the teeth of dogs. Revista Pesquisa Veterinária Brasileira 27(2):85-88. Departamento de Cirurgia, Faculdade de Medicina Veterinária e Zootecnia, Universidade de São Paulo, Av. Prof. Dr. Orlando de Marques de Paiva 87, Bloco 8-superior, Cidade Universitária, São Paulo, SP 05508-000, Brazil. E-mail: lesliedf@usp.br

During endodontic therapy (pulpectomy, root canal debridement and root canal filling) microbiological management is a major concern. Bacteria present in dentine tubules, apical foramina and apical delta are causally related to failure of the procedure. Studies have shown that during single session endodontic treatment bacteria remain within dental structures. The aim of the present study was to evaluate endodontic treatment performed as two sessions, using temporary endodontic dressing materials for different periods in four groups of experimental dogs. A total of 80 roots of second and third upper premolar teeth and second, third and fourth lower premolar teeth were divided into four groups. The pulp chamber was opened with burrs and the pulp exposed for 60 days to induce pulpal inflammation and necrosis. Groups II, III and IV were treated with calcium hydroxide plus camphorated paramonochlorophenol (PMCC) for 7, 15 and 30 days, respectively. In all groups, the root canals were filled with zinc oxide-eugenol and gutta-percha cones. Clinical and radiographical measurements were performed every 2 weeks. After 60 days a small block section containing the teeth, surrounding periapical tissues and the periodontium was removed for histological and microbiological study. Histological analysis revealed intense inflammatory response in all groups. Microbiological analysis showed microbial reduction inversely proportional to the period of time that the intracanal temporary medicament was left in place.
\end{abstract}

INDEX TERMS: Apical delta, endodontic, gutta-percha, camphorated paramonochlorophenol, microorganisms, dogs.

RESUMO.- [Uso do "curativo de demora" em diferentes tempos no tratamento endodôntico de cães com necrose pulpar induzida.] Em um tratamento endodôntico, a microbiota é o ponto primordial a ser levado em consideração, pois as bactérias presentes nos túbulos dentinários, nas foraminas e no delta apical em cães estão relacionadas aos insucessos do proce-

\footnotetext{
${ }^{1}$ Received on October 5, 2006.

Accepted for publication on January 16, 2007.

${ }^{2}$ Post-Graduate student, Departamento de Cirurgia, Faculdade de Medicina Veterinária e Zootecnia (FMVZ), Universidade de São Paulo (USP), Av. Corifeu de Azevedo Marques 87, São Paulo, SP 05508-900, Brazil. "Corresponding author: lesliedf@usp.br

${ }^{3}$ Student of the "Iniciação Científica" Program, Departamento de Cirurgia, FMVZ, USP.

${ }^{4}$ Departamento de Cirurgia, FMVZ, USP.
}

dimento. Estudos revelam que tratamentos realizados em uma única sessão ainda permitem a permanência de bactérias nas estruturas dentárias, portanto propõe-se a execução em duas sessões, com diferentes tempos de "curativo de demora", para verificação da eficácia do protocolo em cães. Foram utilizados no total quatro cães, num total de 80 raízes, provenientes dos $2^{\text {os }}$ e $3^{\text {os }}$ pré-molares superiores e $2^{\underline{o s}}$, $3^{\text {os }}$ e $4^{\text {os }}$ pré-molares inferiores, divididas em quatro grupos de estudo. Nestes foi realizada abertura coronária, onde a polpa ficou exposta por 60 dias. Os Grupos II, III e IV foram tratados. O hidróxido de cálcio com p-monoclorofenol canforado, isto é, a pasta Calen/PMCC (S.S. White Artigos Dentários Ltda, RJ), foi utilizada como "curativo de demora". O Grupo II permaneceu com "curativo de demora" por sete dias, o Grupo III permaneceu por 15 dias e o Grupo IV por 30 dias, todos os grupos foram obturados com cimento à base de óxido de zinco e eugenol - Herodent 
(Vigodent S.A. Indústria e Comércio, SP) e guta-percha. Todos os grupos tiveram controle clínico e radiográfico quinzenal e após 60 dias os dentes foram extraídos em bloco (dente e periodonto) e passaram por processamento laboratorial para realização das análises histopatológica e histomicrobiológica. A análise histopatológica de forma geral mostrou intensa reação inflamatória em todos os grupos estudados, já na análise histomicrobiológica pode-se observar uma diminuição no número de microrganismos proporcional ao tempo de "curativo de demora" deixado intra-canal, portanto a permanência do "curativo" por 30 dias foi a mais eficaz.

TERMOS DE INDEXAÇÃO: Delta apical, endodontia, guta-percha, hidróxido de cálcio com paramonoclorofenolcanforado, microrganismos, cães.

\section{INTRODUCTION}

The role of bacteria in the development of periapical lesions is significant. Reduction of microorganisms is very important in the efficacy of treatments. A study conducted by Domingues (2002) observed the presence of microorganisms inside dentine tubules and apical deltas after single session treatment with different endodontic materials.

The elimination of root canal microorganisms is crucial during necrotic pulp treatment. Bacteria cause and maintain periapical lesion ( Sjogren et al. 1997, Harvey \& Emily 2003).

Endodontic treatment of necrotic pulp is intended to reduce infection to a level that allows the body to respond successfully to the bacterial load. (Fouad et al. 1993).

Tanomaru Filho (2002) and Holland et al. (2003) observed, by histopathological evaluation, that tissue repair of apical and periapical regions was more effective where teeth were treated with calcium hydroxide (double session) compared to definitive obturation (single session).

Other studies (White et al. 1997, Komorowski et al. 2000) showed the importance of temporary endodontic dressing material aimed at bacterial elimination in the apical delta region. Calcium hydroxide has both a bactericidal effect and neutralizes endotoxins (Savafi et al. 1994).

Holland et al. (2005) performed a study to observe the repair process in the teeth of dogs after root canal obturation. They concluded that calcium hydroxide treatment during the procedure promoted the best tissue repair. Sipert et al. (2005) presented similar results.

Vianna et al. (2005) performed an in vitro study that investigated microbial activity of calcium hydroxide $(\mathrm{CH})$ using different adjuvants. It was observed that $\mathrm{CH}$ combined with camphorated paramonochlorophenol (PMCC) was most effective against anaerobic bacteria.

The present study examines the persistence of microorganisms in the root canal, dentine tubules and apical delta of dog's teeth with induced pulp necrosis after two sessions of endodontic treatment, using temporary endodontic dressing cements for different periods of time.

\section{MATERIALS AND METHODS}

The present study was performed in four mixed breed dogs, maintained at the kennel of the Surgery Department of the Veterinary
Medicine School, University of São Paulo, and was approved by the school Ethics Committee. The second, third and fourth lower premolar teeth and the second and third upper premolar teeth of the maxilla were used in the experiment.

\section{Anesthetic Procedure}

The anesthetic protocol utilized for the animals during the surgery procedures (day 0 , day 60 and day 120 ) is described next.

Preanesthetic medication was performed with an intramuscular combination of acepromazine $(0.05 \mathrm{mg} / \mathrm{kg})$ and meperidine $(2 \mathrm{mg} / \mathrm{kg})$, followed by intravenous induction with propofol $(5 \mathrm{mg} / \mathrm{kg})$. For maintenance isoflurane in a $100 \%$ oxygen circuit was used. All animals were maintained on intravenous lactate ringer by catheter placement at the cephalic vein.

Intraoral radiographs were taken every 15 days, until day 120. During these procedures the animals were anesthetized according to the anesthetic protocol described above, except that they were maintained with propofol.

All patients were monitored during the anesthetic procedure by pulse oximeter, indirect blood pressure, electrocardiogram and temperature.

At the end of the day 0 procedure the animals were medicated with a subcutaneous injection of tramadol $(2 \mathrm{mg} / \mathrm{kg})$ and ketoprofen $(1 \mathrm{mg} / \mathrm{kg})$. Postoperative care consisted of oral administration of ketoprofen $(1 \mathrm{mg} / \mathrm{kg} / \mathrm{SID})$ for 5 days with normal diet.

\section{Surgery procedure}

At day 0 , the animals were anesthetized and periapical radiographs of all experimental teeth were taken using the parallel and bisecting angle techniques. Thirty of the forty teeth were opened at the crown to expose the pulp chamber. The remaining 10 teeth were kept intact during this first phase. At the end of the first phase the animals were medicated with anti-inflammatory drugs to control the inflammatory reaction and pain.

After 60 days (considered to be the contamination period) the root canals in the 30 opened teeth were filled. At this time, the 10 intact teeth, comprising the control group, were opened to expose the coronary chamber.

The classical technique of root canal therapy, described by Harvey \& Emily (1993), was performed in this study. Radiographs of the experimental teeth were taken, to evaluate the root canal and periapical region. Endodontic files were placed into each root canal to determine the canal length, and another radiograph was performed to verify the file depth and the working length. The root canal is then cleaned and shaped using the files in a sequential order and with predetermined length, together with irrigation and lubrication with sodium hypochlorite and canal lubricant (endo-PTC $®$ ). The root canal is dried with absorbent paper points and then obturated with filling materials, as calcium hydroxide or zinc-oxide/ eugenol cement with gutta-percha cones.

The 80 roots were divided into four experimental groups: Group I: control (20 roots); Group II: calcium hydroxide/PMCC for 7 days, followed by zinc oxide eugenol paste and gutta-percha (20 roots); Group III: calcium hydroxide/PMCC for 15 days, followed by zinc oxide eugenol paste and gutta-percha (20 roots); and Group IV: calcium hydroxide/PMCC for 30 days, followed by zinc oxide eugenol paste and gutta-percha (20 roots).

After 120 days, the teeth were extracted en bloc (teeth and periodontal tissue). A mucoperiosteal flap is raised over the experimental teeth using a 15 scalpel blade and scissors, followed by ostectomy with chisel and hammer. The specimens were fixed and demineralized for preparation of histological sections. The sectioned specimens were dyed with hematox ylin-eosin (HE) and Brown \& 
Hopps (1973) methods were used to visualise the microorganisms. The non parametric variability method of Kruskal-Wallis was used for statistical analysis and the results were then compared by the Dunn multiple comparison test.

\section{RESULTS AND DISCUSSION}

Histopathological analysis revealed an intense inflammatory reaction in the periapical area (Fig.1). The pattern of inflammatory response was similar in all groups. Thus the root canal exposure to contamination with induced pulp necrosis was sufficient to promote the periapical inflammatory process.

Contrary to the findings of Holland et al. (2003) the use of temporary endodontic dressings did not reduce the inflammatory reaction. However, there was a significant difference in the inflammatory pattern together with the region affected and the severity, group I revealed an intense inflammatory reaction together Group II and Group III, only Group IV revealed significant moderate inflammatory reaction $(p>0.05)$.

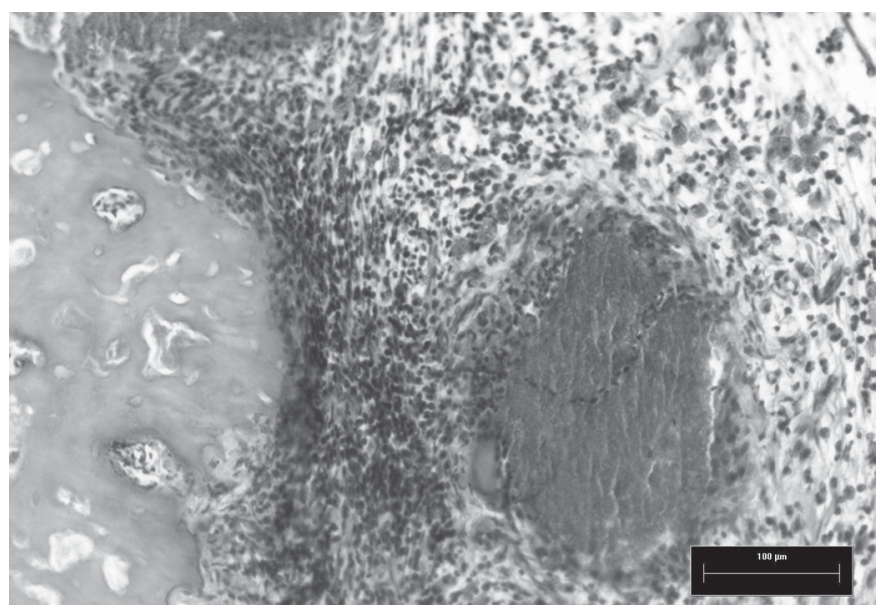

Fig.1. Radicular apical region (Group: control), showing infiltration and inflammatory response (star). HE, obj.10.

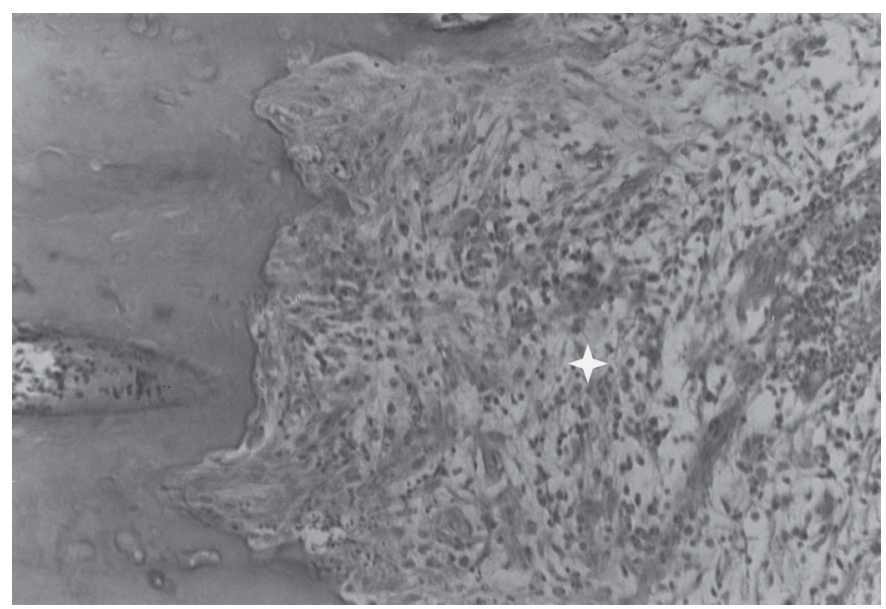

Fig.2. Radicular apical region (Group IV: CH/PMCC for 30 days, followed by zinc oxide eugenol paste and gutta-percha), showing infiltration and inflammatory response the more severe the reaction, reaching periapical alveolar bone at 30 days (star). HE, obj.10.

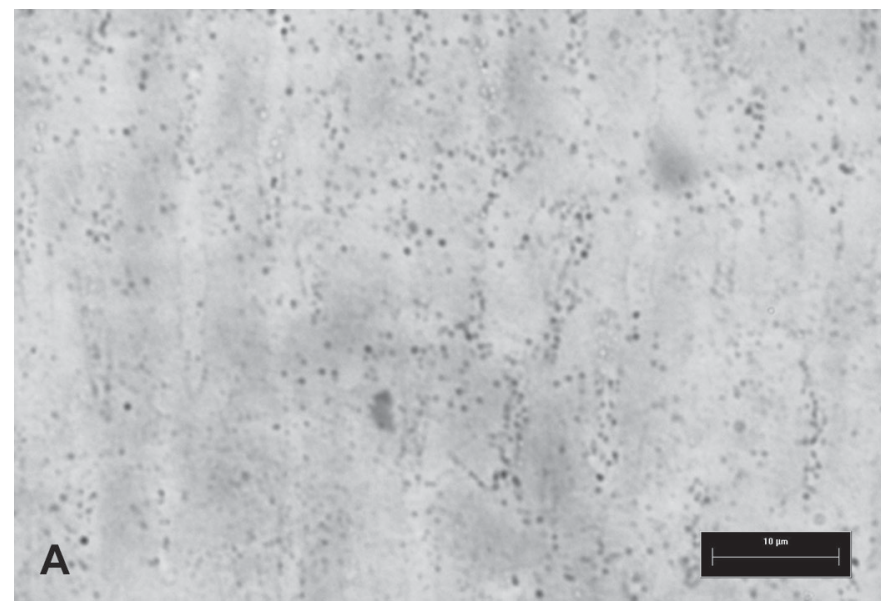

B

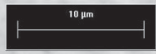

Fig.3. Microorganisms present in dentine tubules in Group I: control (A) and Group IV: 30 days with CH/PMCC (B). BH (Brown \& Hopps 1973), obj.100.

The longer the period of temporary endodontic dressings were left in the root canal, the deeper the effect penetrated and the more severe the reaction; reaching periapical alveolar bone at 30 days (Fig.2). This would be expected since calcium hydroxide causes an inflammatory response when used alone, but in association with PMCC the response is more severe since PMCC is more aggressive to tissues. The treatment is recommended by some authors for short periods (Savafi et al. 1994).

The presence of bacteria in the apical delta and dentine tubules were analyzed in all groups. Longer periods of calcium hydroxide lead to a lower percentage of bacteria in these regions (Savafi et al. 1994). Although even at 30 days of temporary endodontic dressing there was still evidence of microorganisms (Fig.3).

As well as the delta and dentine tubules the inside of the root canals were also evaluated. A complete removal of microorganisms could be observed at day 7 . Only the control group presented microorganisms inside the root canal.

When evaluating bacteria in the dentine tubules, located at the apical third, there was a significant reduction of bacteria proportional to the period of the temporary endodontic dressing cements $(p>0.05)$. However even after 


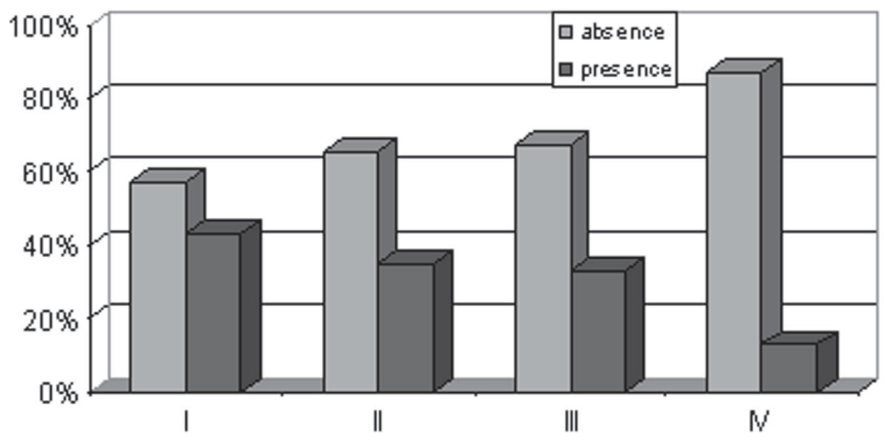

Fig.4. Microorganisms present or absent in the dentine tubules located in the apical third of the $\operatorname{dog}$ root $(\mathrm{p}>0.05)$ (Group I: control; Group II: 7 days with CH/PMCC; Group III: 15 days with $\mathrm{CH} / \mathrm{PMCC}$, and Group IV: 30 days with $\mathrm{CH} / \mathrm{PMCC}$.

30 days of exposure bacteria could still be observed in this region (Fig.4).

The histomicrobiological analysis demonstrated that the presence of temporary endodontic dressing reduces microbial loading, agreeing with Holland et al. (2005) and Vianna et al. (2005). The control group showed the highest concentrations of microorganisms. There was a decrease proportional to the exposure time to the temporary endodontic dressing cements in the root canal. This agreed with Vianna et al. (2005) in demonstrating the bactericidal effect of calcium hydroxide. It also showed that PMCC promoted the anti-bacterial effect. Significantly however, even after 30 days of treatment microorganisms were still found in some of the studied regions.

The periods (7, 15 and 30 days) of temporary endodontic dressing cement in the root canal were not sufficient to totally eliminate bacteria in all regions; bacteria were present in the dentine tubules and apical delta. Complete removal is considered essential for a good prognosis of endodontic treatment. Other studies are necessary in order to establish an efficient endodontic treatment.

Acknowledgments.- To the "Fundação de Amparo à Pesquisa do Estado de São Paulo" (FAPESP) for funding this Project.

\section{REFERENCES}

Brown J.H. \& Hopps H.C. 1973. Staining of bacteria in tissue sections: a reliable Gram stain method. Am. J. Clin. Pathol. 60(2):234-240.

Domingues L.M. 2002. Análise histológica, histomicrobiológica e radiológica de dentes de cães com necrose pulpar, induzida experimentalmente, submetidos a diferentes materiais dentários. Tese de Doutorado em Cirurgia Veterinária, Faculdade de Ciências Agrárias e Veterinárias, Universidade Estadual Paulista, Jaboticabal. 92p.

Fouad A.F., Walton R.E. \& Rittman B.R. 1993. Healing of induced periapical lesions in ferret canines. J. Endodon. 19:123-129.

Harvey C.E. \& Emily P.P. 1993. Small Animal Dentistry. Mosby-Year Book, St Louis. 413p.

Holland R., Otoboni Filho J.A., Souza V., Juvenal Rery M., Bernabé P.F.E. \& Dezan E. 2003. A comparison of one versus two appointment endodontic therapy in dog's teeth with apical periodontitis. J. Endodon. 29(2):121125.

Holland R., Sant'Anna Jr A., Souza V., Dezan Jr E., Otoboni Filho J.A., Bernabé P.F.E., Nery M.J. \& Murata S.S. 2005. Influence of apical patency and filling material on healing process of dogs' teeth with vital pulp after root canal therapy. Braz. Dent. J. 16(1):9-16.

Komorowski R., Grad H., Wu X.Y. \& Friedman S. 2000. Antimicrobial substantivity of chlorhexidine-treated bovine root dentin. J. Endodon. 26:315-317.

Safavi K.E. \& Nichols F.C. 1994. Alteration of biological properties of bacterial lipopolysaccharide by calcium hydroxide treatment. J. Endodon. 20:127129.

Sipert C.R., Hussne R.P., Nishiyama C.K. \& Torres S.A. 2005. In vitro antimicrobial activity of fill canal, sealapex, mineral trioxide aggregate, Portland cement and endorez. Int. Endodon. J. 38:539-543.

Sjögren U., Fidgor D., Persson S. \& Sundqvist G. 1997. Influence of infection at the time of root filling on the outcome of endodontic treatment of teeth with apical periodontitis. Int. Endodon. J. 30:297-306.

Tanomaru Filho M., Leonardo M.R. \& Silva L.A.B. 2002. Effect of irrigation solution and calcium hydroxide root canal dressing on the repair of apical and periapical tissues of teeth with periapical lesion. J. Endodon. 28(4):295299.

Vianna M.E., Gomes B.P.F.A., Sena N.T., Zaia A.A., Ferraz C.C.R. \& Souza Filho FJ. 2005. In vitro evalutation of the susceptibility of endodontic pathogens to calcium hydroxide combined with different vehicles. Braz. Dent. J. 16(3):175-180.

White R.R. 1997. Residual antimicrobial activity after canal irrigation with chlorhexidine. J. Endodon. 23:229-231. 